\title{
ACCURACY OF THE RADIOCARBON TIME SCALE BEYOND 15,000 BP
}

\author{
J C VOGEL \\ CSIR, Box 395, Pretoria, South Africa
}

ABSTRACT. Ionium dates for the Upper Lisan Formation in the Dead Sea valley average $(10 \pm 3)$ percent higher than a set of radiocarbon dates from the same profiles. No analytical explanation can be found so that the discrepancy may be real for the period 15,000 BP to 35,000 BP (conventional radiocarbon years). This would have implications for the chronology of the Upper Pleistocene.

\section{INTRODUCTION}

Carbon-14 analyses of dendrochronologically dated wood samples have demonstrated that radiocarbon dates deviate progressively from the true age between the beginning of the Christian era and 5000 BC (Suess, 1970). At the latter date, radiocarbon ages are already about 800 years too young. Several attempts have been made to assess the accuracy of radiocarbon dates in the period beyond the present range of the tree-ring sequence by using various varve sequences (Tauber, 1970; Stuiver, 1970; Vogel, 1970; Yang and Fairhall, 1971). Results of such attempts show marked disagreement (fig 1). At present, we can only state that radiocarbon dating of the beginning of the Holocene $(10,000$ conventional radiocarbon years $\mathrm{BP}$ or 10,300 years $\mathrm{BP}$, if the more correct half-life of 5730 years for ${ }^{14} \mathrm{C}$ is used) apparently correlates with dating based on Scandinavian varve chronology to within \pm 300 years (Vogel, 1970). The deviation in radiocarbon ages, thus, seems to decrease as the Holocene/ Pleistocene boundary is approached.

Beyond this time, it becomes increasingly difficult to verify the validity of radiocarbon dates. One possibility is comparison with ionium $\left({ }^{230} \mathrm{Th}\right)$ dates on the same sediments. This has been undertaken by Kaufman and Broecker (1965) for Lake Bonneville and Lake Lahontan sediments. For the range 10,000 to 20,000 years, they estimate the ratio of ${ }^{230} \mathrm{Th}$ to ${ }^{14} \mathrm{C}$ ages to be $1.10 \pm 0.11$, ie, the ${ }^{14} \mathrm{C}$ dates are on the average 10 percent younger although the discrepancy is not significant. More recently, Peng, Goddard, and Broecker (1978) and Stuiver (1978) have compared ${ }^{14} \mathrm{C}$ and ${ }^{230} \mathrm{Th}$ dates on sediments from Searles Lake. After applying corrections to both sets of data, Peng, Goddard, and Broecker conclude that there is no observable difference between them, while Stuiver, apparently using a different correction for the ${ }^{14} \mathrm{C}$ dates and the correct half-life, finds them to be about 700 years younger on the average.

\section{Dating of the Lisan Formation}

A further set of data is available for such comparison from the chalk deposits of the fossil Lake Lisan in the Dead Sea basin between Israel and Jordan. Remnants of these lacustrine deposits are extensively exposed along the length of the Jordan/Dead Sea valley down to some $20 \mathrm{~km}$ south of Sedom, indicating the great extent of the Pleistocene Lake (Neev and Emery, 1967). The sediments of the Upper Lisan Formation show a distinct layering of white and grayish material, the 


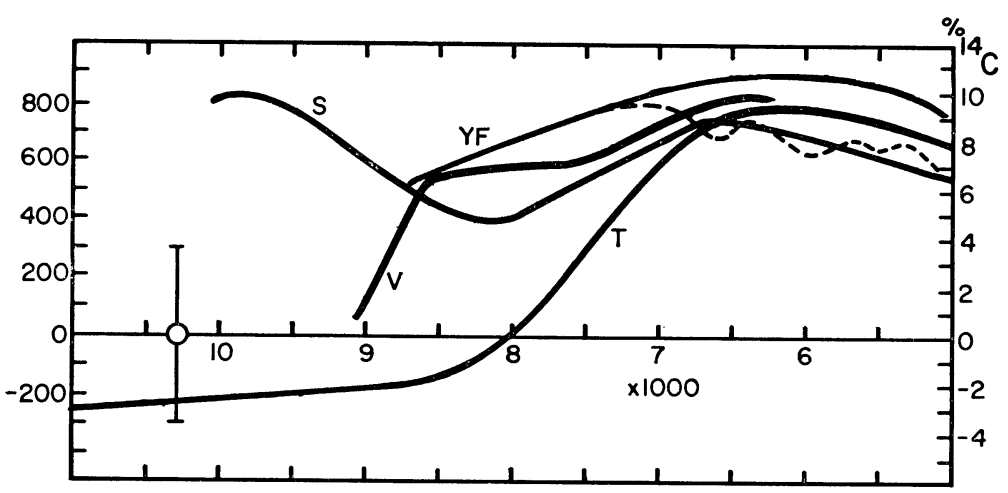

Fig 1. Estimates of the deviation in the ${ }^{14} \mathrm{C}$ content of the atmosphere between 5000 and 11,000 BP based on varve chronologies. Dashed line is the curve derived from tree rings (Suess, 1970).

T: Tauber (1970). Scandinavia.

S: Stuiver (1970). Lake of Clouds, Minnesota, USA.

V: Vogel (1970). Faulensee, Switzerland.

YF: Yang and Fairhall (1971). Saanish Inlet, British Columbia.

The end of the Last Glacial, according to the Scandinavian varve chronology, is dated to $10,300 \pm 300 \mathrm{BP}$, and according to the Northern European pollen diagrams, radiocarbon dated to 10,300 BP (Vogel, 1970) so that, at this point in time, the discrepancy
is less than 3 percent.

former being practically pure aragonite and the latter a mixture of silicate and calcite. They are, thus, similar to the basal deposit forming in the Dead Sea today. Here, dark detrital material alternates with white aragonite laminae which are precipitated, from time to time, when the water becomes over-saturated (Neev, 1962). Underlying the upper member of the Lisan Formation is the lower Lisan, mainly composed of detrital deposit intercalated occasionally with laminated chalk.

The inorganically deposited aragonite from this arid environment provides ideal material for both ${ }^{230} \mathrm{Th}$ and ${ }^{14} \mathrm{C}$ dating since it most probably represents a closed system with little possibility of post-depositional contamination. Kaufman (1971) made a very successful study of the uranium series isotopes in a number of samples from the Lisan Formation. By analyzing different fractions of the clear and dark laminae separately, he could eliminate the uncertainty of the initial thorium content and obtain dates that are more trustworthy than is usually the case. The results relevant to this discussion are listed in table 1 .

${ }^{14} \mathrm{C}$ analyses were performed on two sets of samples from the same locations at which the ${ }^{230} \mathrm{Th}$ samples were collected (table 2). Those from Location $1,1 \mathrm{~km}$ east of Masada, had been collected previously, while the sample set from Location 2, $5 \mathrm{~km}$ northwest of Sedom, consisted of portions of the samples used for ionium dating. The results obtained on sediment from the present Dead Sea are included in table 2 for comparison. The mainly dark laminae (H2005b), when compared with the white laminae (H2005a) clearly show that this predominantly detrital fraction contains an appreciable amount of old carbon, pre- 
TABLE 1

Ionium dates for Lisan samples (Kaufman, 1971)

\begin{tabular}{|c|c|c|}
\hline Sample & Depth (m) & ${ }^{200} \mathrm{Th} /{ }^{234} \mathrm{U}$ age (yrs) \\
\hline $\begin{array}{l}\text { Location } 1 \\
21 \mathrm{C} \\
24 \mathrm{~B}\end{array}$ & $\begin{array}{c}5 \\
13 * \\
\end{array}$ & $\begin{array}{l}24,000 \pm 3000 \\
37,000 \pm 3000\end{array}$ \\
\hline $25 \mathrm{~B}$ & 20 & $45,000 \pm 5000$ \\
\hline $\begin{array}{l}\text { Location } 2 \\
35 \mathrm{D} \\
35 \mathrm{C} \\
35 \mathrm{~B} \\
35 \mathrm{~A}\end{array}$ & $\begin{array}{c}0 \\
3 \\
12 \\
18 * \\
\end{array}$ & $\begin{array}{c}20,000 \pm 2000 \\
21,000 \pm 2000 \\
30,500 \pm 2500 \\
40,000 \pm 2500\end{array}$ \\
\hline $\begin{array}{l}36 \\
37 \mathrm{~A} \\
\end{array}$ & $\begin{array}{l}26 \\
46 \\
\end{array}$ & $\begin{array}{l}48,000 \pm 4000 \\
60,000 \pm 4000\end{array}$ \\
\hline $\begin{array}{l}\text { Location } 4 \\
34 \mathrm{~B} \\
33 \mathrm{~A}\end{array}$ & $\begin{array}{c}0 \\
19 * \\
\end{array}$ & $\begin{array}{r}17,000 \pm 2000 \\
46,500 \pm 3000\end{array}$ \\
\hline 32 & 40 & $61,000 \pm 6000$ \\
\hline
\end{tabular}

* Base of Upper Lisan Formation.

sumably in the form of carbonate grains. The same holds true for the pairs $35 \mathrm{D}$ and $35 \mathrm{~B}$ from Location 2 : the ${ }^{14} \mathrm{C}$ content of the fairly dark (FD) fraction is lower than that of the very clear (VC) fraction, indicating, in both cases, 11 percent ancient carbonate in the FD fractions. The dates for the VC fractions should, thus, be given preference.

The dates obtained for the two samples from the lower member of the Lisan Formation (LO and 36) are clearly much too young when compared with the results for the overlying samples. This can be explained by assuming post-depositional contamination. Both were collected low down in the sequence in stormwater gullies that are regularly wetted. The other samples from the upper member show a linear increase of age with depth and, therefore, seem to be reliable.

In figure 2, both the ${ }^{14} \mathrm{C}$ and ${ }^{230} \mathrm{Th}$ ages are plotted against their relative depth in the Upper Lisan Formation. Also included is a date for a piece of driftwood found at $6 \mathrm{~m}$ depth at Location 1 (analyzed at Lamont, 25,000 \pm 1000 BP; Kaufman, 1971). The ${ }^{14} \mathrm{C}$ ages lie very closely on a straight line, suggesting a linear rate of deposition. However, the best straight line through the ${ }^{230} \mathrm{Th}$ dates is significantly displaced towards higher ages with respect to that for the ${ }^{14} \mathrm{C}$ dates, indicating a discrepancy of $(10 \pm 3)$ percent between the two sets of data. (Note that the more correct ${ }^{14} \mathrm{C}$ half-life of 5730 years has been used in the plot).

\section{Reliability of dates}

Possible reasons for this discrepancy need careful consideration.

1) Ionium dates. The correction for initial ${ }^{230} \mathrm{Th}$ could be made with confidence by comparing different fractions of the same sample so that this effect could hardly introduce an error. The other possibility, that 
uranium was added subsequent to precipitation, would make the samples appear younger, and not older, than they should be.

2) Radiocarbon dates. No correction for the initial ${ }^{14} \mathrm{C}$ content of the carbonate has been applied. If the dissolved bicarbonate in the water of Lake Lisan was in complete isotopic equilibrium with atmospheric carbon dioxide, the ${ }^{14} \mathrm{C}$ content of the precipitated carbon would have been 105 percent that of modern carbon. This is because isotopic fractionation effects cause the ${ }^{14} \mathrm{C} /{ }^{12} \mathrm{C}$ ratio in the dissolved bicarbonate to be about 5 percent higher than that of contemporaneous wood (cf, the $\delta^{13} \mathrm{C}$ values); 400 years would then have to be added to the calculated ages. It can, however, safely be assumed that the water feeding the lake would have a considerable deficiency in ${ }^{14} \mathrm{C}$ (Vogel and Ehhalt, 1963). This value would gradually rise as a result of isotopic exchange with the atmosphere and the ultimate value would depend on the average residence time of the bicarbonate in the lake water.

Today, the dissolved carbon in both surface and deep water in the Dead Sea contains about 82 percent as much ${ }^{14} \mathrm{C}$ as modern wood (table 3, courtesy K O Münnich). If similar conditions prevailed in Lake Lisan,

TABLE 2

Carbon isotope analyses and ${ }^{14} \mathrm{C}$ ages of carbonates from the Lisan Formation and from the Dead Sea* for comparison

\begin{tabular}{|c|c|c|c|c|c|c|c|c|c|}
\hline Sample & $\begin{array}{l}\text { Dep:h } \\
(\mathrm{m})\end{array}$ & $\begin{array}{c}\text { Carb } \\
(\%)\end{array}$ & $\begin{array}{l}\delta^{18} \mathrm{O} \\
(\% / c)\end{array}$ & $\begin{array}{l}\delta^{1:} \mathrm{C} \\
(\% / c c)\end{array}$ & $\begin{array}{c}\text { Carb } \\
(\%)\end{array}$ & $\begin{array}{l}\delta^{13} \mathrm{C} * * \\
(\% \text { \% })\end{array}$ & $\begin{array}{l}{ }^{14} \mathrm{C} \text { content } \\
(\% \text { modern })\end{array}$ & $\begin{array}{c}\text { App }{ }^{14} \mathrm{C} \text { age } \\
\text { (years) }\end{array}$ & $\begin{array}{l}\text { Lab } \\
\text { no. }\end{array}$ \\
\hline $\begin{array}{l}\text { Location } 1 \\
\text { L3 } \\
\text { L2 } \\
\text { L1 }\end{array}$ & $\begin{array}{c}1 \\
10 \\
14 \#\end{array}$ & $\begin{array}{l}53 \\
65 \\
3.0\end{array}$ & $\begin{array}{l}+2.5 \\
+3.9 \\
+2.5\end{array}$ & $\begin{array}{r}0.0 \\
-0.3 \\
+1.5\end{array}$ & $\begin{array}{l}45 \\
66 \\
3.2\end{array}$ & $\begin{array}{r}0.0 \\
+0.1 \\
+0.6\end{array}$ & $\begin{array}{r}13.20 \pm .12 \\
2.01 \pm .08 \\
1.28 \pm .15\end{array}$ & $\begin{array}{l}16,300 \pm 75 \\
31,400 \pm 310 \\
35,000 \pm 900\end{array}$ & $\begin{array}{r}\text { GrN- } \\
4403 \\
4402 \\
4401\end{array}$ \\
\hline Lo & 19 & 86 & +4.9 & -0.4 & 63 & - & $4.05 \pm .12$ & $25,800 \pm 240$ & $\overline{44} \overline{11}$ \\
\hline $\begin{array}{l}\text { Location } 2 \\
\text { 35D-VC } \\
35 \mathrm{D}-\mathrm{FD} \\
35 \mathrm{~B}-\mathrm{VC} \\
45 \mathrm{~B}-\mathrm{FD}\end{array}$ & $\begin{array}{c}0 \\
0 \\
12 \# \\
12 \#\end{array}$ & $\begin{array}{l}\overline{-} \\
\overline{92} \\
50\end{array}$ & $\begin{array}{r}- \\
+\overline{4.0} \\
+3.2\end{array}$ & $\begin{array}{r}- \\
+1.4 \\
+0.6\end{array}$ & $\begin{array}{l}80 \\
54 \\
78 \\
60\end{array}$ & $\begin{array}{l}+1.5 \\
+1.8 \\
+1.7 \\
+0.8\end{array}$ & $\begin{array}{r}15.20 \pm .21 \\
13.56 \pm .25 \\
2.70 \pm .13 \\
2.41 \pm .16\end{array}$ & $\begin{array}{l}15,150 \pm 110 \\
16,100 \pm 150 \\
29,000 \pm 380 \\
29,900 \pm 530\end{array}$ & $\begin{array}{l}4837 \\
4838 \\
4841 \\
4842\end{array}$ \\
\hline $\begin{array}{l}36-\mathrm{VC} \\
36-\mathrm{FC}\end{array}$ & $\begin{array}{l}26 \\
26\end{array}$ & $\begin{array}{l}78 \\
68 \\
\end{array}$ & $\begin{array}{l}+3.8 \\
+4.0\end{array}$ & $\begin{array}{l}+0.3 \\
+0.4\end{array}$ & $\begin{array}{l}75 \\
73\end{array}$ & $\begin{array}{l}+0.3 \\
+0.7\end{array}$ & 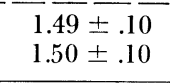 & $\begin{array}{l}33,850 \pm 510 \\
33,800 \pm 530\end{array}$ & $\begin{array}{l}\overline{4844} \\
4843\end{array}$ \\
\hline $\begin{array}{l}\text { Dead Sea s } \\
\text { H2005a } \\
\text { H2005b }\end{array}$ & ediment & & $\begin{array}{l}+2.4 \\
-1.0\end{array}$ & $\begin{array}{l}+2.8 \\
+0.5\end{array}$ & $\begin{array}{l}\text { c. } 50 \\
\text { c. } 25\end{array}$ & $\begin{array}{l}+0.8 \\
-0.8\end{array}$ & $\begin{array}{l}56.9 \pm .5 \\
29.2 \pm .5\end{array}$ & $\begin{array}{l}4530 \pm 70 \\
9890 \pm 140\end{array}$ & $\begin{array}{c}\text { H- } \\
1423 \\
1424\end{array}$ \\
\hline
\end{tabular}

* The sample of Dead Sea sediment was collected by D Neev and separated into two fractions (H2005a: mainly white and H2005b: mainly dark laminae), and ${ }^{14} \mathrm{C}$ dated by $\mathrm{K} O \mathrm{O}$ Münnich, who kindly supplied portions for ${ }^{18} \mathrm{O}$ and ${ }^{14} \mathrm{C}$ analysis.

${ }^{* * *}{ }^{13} \mathrm{C}$ measured on ${ }^{14} \mathrm{C}$ sample.

+ Samples separated by A Kaufman into very clear (VC), fairly clear (FC), fairly dark (FD) and very dark (VD) fractions. The VC fractions thus contain mainly aragonite while the FC and FD fractions have a higher proportion of de rital matcrial including calcite and possibly some dolomite washed into the lake.

$\ddagger$ Apparent ${ }^{14} \mathrm{C}$ age calcula:ed wi:h conventional half-life of 5568 years and not corrected for isotope fractionation.

\# Base of Upper Lisan Formation. 


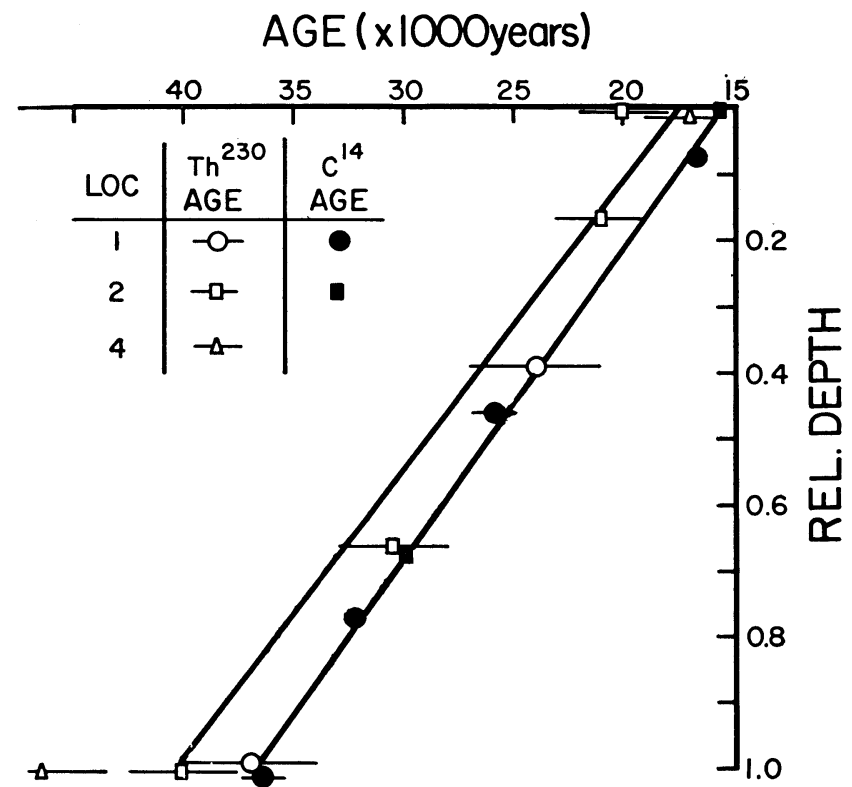

Fig 2. Age of Upper Lisan sediments plotted against relative depth in the sequence. Open signs: ionium dates; closed signs: radiocarbon dates. The best straight lines drawn through the two sets of data deviate by $10 \pm 3$ percent from each other.

1600 years would have to be subtracted from the ${ }^{14} \mathrm{C}$ dates, thus increasing the discrepancy with regard to the ${ }^{230} \mathrm{Th}$ dates. Since, however, we have no reason to assume that the residence times in Lake Lisan and the Dead Sea are similar, no estimate of the size of the required correction to the dates can be made. Comparison with the date for a wood sample (see below) suggests that the necessary adjustment is not large.

Post-depositional contamination with younger carbon would make the ${ }^{14} \mathrm{C}$ dates too young. The aridity of the environment would limit such an exchange and if moist conditions had occurred, a loss of soluble salts and conversion of aragonite to calcite would have resulted (Katz and Kolodny, 1977). These authors observed Lisan aragonite in distilled water to transform completely to calcite within 36 hours, and conclude that chemical and isotopic alteration has been negligible. These arguments, however, do not apply to the two samples (LO and 36) from the Lower Lisan for reasons given above.

TABLE 3

Carbon isotope content of Dead Sea water*

\begin{tabular}{lrrrrr}
\hline $\begin{array}{c}\text { Sample and } \\
\text { analysis no. }\end{array}$ & Date & Depth & $\delta^{13} \mathrm{C} \%$ cont & $\begin{array}{c}{ }^{14} \text { Cicontent } \\
\% \text { modern }\end{array}$ & $\begin{array}{c}\text { App } \\
\text { age }\end{array}$ \\
\hline H2018-1434 & 18.01 .1963 & $0 \mathrm{~m}$ & +1.7 & $82.7 \pm .5$ & 1530 \\
H2040-1455 & 8.05 .1963 & $0 \mathrm{~m}$ & +2.0 & $82.2 \pm .6$ & 1570 \\
H2026-1445 & 04.1963 & $75 \mathrm{~m}$ & $-1.6(?)$ & $75.5 \pm 1.0$ & 2260 \\
H1937-1343 & 09.1962 & $250 \mathrm{~m}$ & +1.2 & $81.1 \pm 1.2$ & 1680 \\
\hline
\end{tabular}

* Courtesy of K O Münnich. 
The trustworthiness of the ${ }^{14} \mathrm{C}$ dates is further confirmed by their close correspondence with the single date on the driftwood sample (fig 2). We, therefore, conclude that the discrepancy between the $8^{230} \mathrm{Th}$ and 6 ${ }^{14} \mathrm{C}$ dates from these deposits is real. If we accept this conclusion, it would either be explained by postulating that the ${ }^{230} \mathrm{Th}$ half-life of 75,200 years is 10 percent too high, or by assuming that the ${ }^{14} \mathrm{C}$ content of the atmosphere was much higher during the Pleniglacial than in recent times (26 percent at 17,000 $\mathbf{B P}$ increasing to 55 percent at $40,000 \mathrm{BP} !)$. The other two comparisons mentioned previously (Lakes Bonneville and Lahontan, and Searles Lake) would not necessarily contradict the data presented here, since there are several uncertainties inherent in those analyses.

In view of the implications of these conclusions, it seems highly desirable that more such comparisons be made on carefully selected material. The parallel dating of coral or speleothems seems to offer the greatest promise in this respect.

\section{Dating of the Early Last Glacial}

Whatever the reason for the 10 percent difference between ${ }^{14} \mathrm{C}$ and ${ }^{230} \mathrm{Th}$ dates may be, it is worthwhile considering briefly what effect it would have on our present understanding of the chronology of the Upper Pleistocene.

Considerable effort has been invested in the radiocarbon dating, by thermal diffusion enrichment of ${ }^{14} \mathrm{C}$, of the early part of the Last Glacial period as observed in Europe (Haring, de Vries, and de Vries, 1958; Vogel and Zagwijn, 1967; Grootes, 1977; 1978). The ${ }^{14} \mathrm{C}$ dates for the three Early Glacial interstadials are shown in figure 3. The best inferred dating of the beginning of these interstadials is summarized in table 4 . In view of the extreme contamination problem inherent in this time range, the dates are always to be regarded as minimum. If, however, they are taken at face value (column 2, table 4) and compared with ionium dates for the raised beaches in Barbados (Mesolella and others, 1969) and New Guinea (Bloom and others, 1974) and their correlation with the ${ }^{18} \mathrm{O}$ climatic record of the deep sea cores, it must be concluded that the Early Glacial period falls within Stage 4 of this record (Shackleton and Opdyke, 1973; Grootes, 1978).

TABLE 4

Derived radiocarbon dates for the beginning of Early Glacial Interstadials in Northern Europe (Grootes, 1977; 1978) (see fig 3)

\begin{tabular}{lccc}
\hline & \multicolumn{3}{c}{ Age $(\mathrm{yr})$} \\
\cline { 2 - 4 } Interstadial & $\left(\mathrm{t}_{1 / 2}=5568\right)$ & $\left(\mathrm{t}_{1 / 2}=5730\right)$ & $+10 \%$ \\
\hline Amersfoort & $68,200 \pm 1100$ & 70,250 & 77,280 \\
Brørup & $64,400 \pm 800$ & 66,330 & 72,960 \\
Odderade & $60,500 \pm 600$ & 62,320 & 68,550 \\
\hline
\end{tabular}




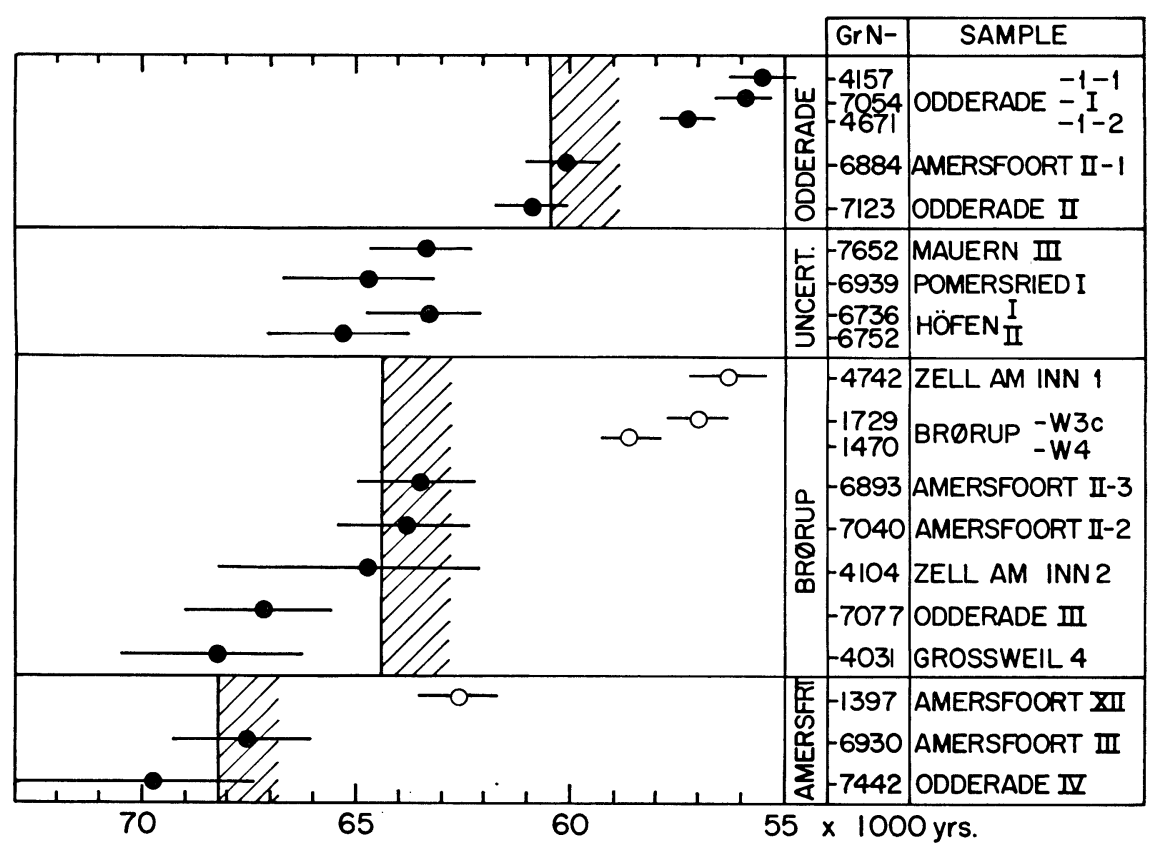

Fig 3. Enriched radiocarbon dates for Early Glacial interstadials in Northern Europe (Grootes, 1977; 1978; Vogel and Zagwijn, 1967). Open circles are dates which must be rejected because they are younger than those for the succeeding stage.

On the other hand, the Last Interglacial (Eemian) is currently correlated with Stage 5e (Shackleton, 1969; Mangerud, S $\phi$ nstegaard, and Sejrup, 1979) which implies that Stages 5d-a already belong to the Last Glacial period, and suggests, furthermore, that the warmer Stages, $5 \mathrm{c}$ and $5 \mathrm{a}$, belong to the early Weichsel/Würm interstadials. This would mean that these interstadials correlate with the high sea levels, Barbados II and $\mathrm{I}$, and date to $105,000 \mathrm{BP}$ and $82,000 \mathrm{BP}$, which is in complete disagreement with the ${ }^{14} \mathrm{C}$ dates in figure 3 .

If we use Zagwijn's definition of the Last Interglacial as the first period before the Last Ice Age, when it was at least as warm as at present, we must accept that this Eemian Interglacial is a recognizable entity in Northern Europe (Kukla, 1977). In view of the fact that the deep sea ${ }^{18} \mathrm{O}$ record is increasingly being used for worldwide correlations, it appears to be a matter of some urgency to definitely establish where the Last Glacial begins in this record. If the ${ }^{14} \mathrm{C}$ dates, with or without the more correct half-life (columns 2 and 3, table 4) are directly comparable with the ${ }^{230} \mathrm{Th}$ dates, the boundary lies between Stages 5 and 4 , and the whole of Stage 5 would correlate with the Eemian. However, if the ${ }^{14} \mathrm{C}$ dates are to be increased by 10 percent (table 4, column 4), the Amersfoort Interglacial would be contemporaneous with Stage 5a and the beginning of the Last Ice Age would have to be at the Stage $5 \mathrm{c} / 5 \mathrm{~b}$ boundary. 
It would be easy to argue that all the ${ }^{14} \mathrm{C}$ dates of this period are too young due to contamination, and to accept Shackleton's correlation that the Last Ice Age starts with Stage 5 d at ca 120,000 BP. This would, however, also raise doubts as to the validity of the Pleniglacial chronology as established by van der Hammen and others (1967). It would also seriously question the advisability of the considerable effort now being invested in the extension of radiocarbon dating by ion counting.

\section{REFERENCES}

Bloom, A L, Broecker, W S, Chappell, J M A, Matthews, R K, and Mesolella, K J, 1974, Quaternary sea level fluctuations on a tectonic coast: new ${ }^{230} \mathrm{Th} /{ }^{234} \mathrm{U}$ dates from the Huon peninsula, New Guinea: Quaternary Research, v 4, p 185-205.

Grootes, P M, 1977, Thermal diffusion isotopic enrichment and radiocarbon dating beyond 50,000 years BP: Thesis, Univ Groningen, p 221. v 200, p $11-15$.

Haring, A, de Vries, A E, and de Vries, H, 1958, Radiocarbon dating up to 70,000 years by isotopic enrichment: Science, v 128, p 472-473.

Katz, A and Kolodny, Y, 1977, The geochemical evolution of the Pleistocene Lake Lisan-Dead Sea system: Geochim et Cosmochim Acta, v 41, p 1609-1626.

Kaufman, Aaron, 1971, U-series dating of Dead Sea basin carbonates: Geochim et Cosmochim Acta, v 35, p 1269-1281.

Kaufman, Aaron and Broecker, W S, 1965, Comparison of $\mathrm{Th}^{230}$ and $\mathrm{C}^{14}$ ages for carbonate materials from Lakes Lahontan and Bonneville: Jour Geophys Research, v 70, p 4039-4054.

Kukla, G J, 1977, Pleistocene land-sea correlations. 1. Europe: Earth-Sci Rev, v 13, p $307-374$.

Mangerud, J, Sønstegaard, E, and Sejrup, H-P, 1979, Correlations of the Eemian (interglacial) stage and the deep-sea oxygen-isotope stratigraphy: Nature, v 277, p 189-192.

Mesolella, K J, Matthews, R K, Broecker, W S, and Thurber, D L, 1969, The astronomical theory of climatic change: Barbados data: Jour Geology, v 77, p $250-274$.

Neev, D, 1962, Recent precipitation of calcium salts in the Dead Sea: Research Council Israel Bull, Sec G, v 11 G.

Neev, D and Emery, K O, 1967, The Dead Sea: Israel Geol Survey Bull, no. 41, p 1-147.

Peng, T-H, Goddard, J G, and Broecker, W S, 1978, A direct comparison of ${ }^{14} \mathrm{C}$ and ${ }^{230} \mathrm{Th}$ ages at Searles Lake, California: Quarternary Research, v 9, p 319-329.

Shackleton, N J, 1969, The last interglacial in the marine and terrestrial records: Royal Soc (London) Proc, B 174, p 135-154.

Shackleton, N J and Opdyke, N D, 1973, Oxygen isotope and palaeomagnetic stratigraphy of Equatorial Pacific Core V 28-238: oxygen isotope temperatures and ice volumes on a $10^{5}$ year and $10^{8}$ year scale: Quaternary Research, v 3, p 30-55.

Stuiver, Minze, 1970, Long-term C-14 variations, in Olsson, I U, ed, Radiocarbon variations and absolute chronology, Nobel symposium, 12th, Proc: New York, John Wiley and Sons, p 197-213.

1978, Radiocarbon timescale tested against magnetic and other dating methods: Nature, v 273, p 271-274.

Suess, H E, 1970, Bristlecone-pine calibration of the radiocarbon time-scale $5200 \mathrm{BC}$ to the present, in Olsson, I U, ed, Radiocarbon variations and absolute chronology, Nobel symposium, 12th, Proc: New York, John Wiley and Sons, p 303-311.

Tauber, Henrik, 1970, The Scandinavian varve chronology and C-14 dating, in Olsson, I U, ed, Radiocarbon variations and absolute chronology, Nobel symposium, 12th, Proc: New York, John Wiley and Sons, p 173-196.

Van der Hammen, T, Maarleveld, G C, Vogel, J C, and Zagwijn, W H, 1967, Stratigraphy, climatic succession and radiocarbon dating of the Last Glacial in the Netherlands: Geol en Mijnbouw, v 46, p 79-95.

Vogel, J C, 1970, C-14 trends before 6000 BP, in Olsson, I U, ed, Radiocarbon variations and absolute chronology, Nobel symposium, 12th, Proc: New York, John Wiley and Sons, p. 313-325. 
Vogel, J C and Ehhalt, D, 1963, The use of carbon isotopes in groundwater studies, in Radioisotopes in hydrology: Vienna, IAEA, p 383-395.

Vogel, J C and Zagwijn, W H, 1967, Groningen radiocarbon dates VI: Radiocarbon, v 9, p 63-106.

Yang, A In Che and Fairhall, A, 1972, Variations of natural radiocarbon during the last 11 millenia (sic!) and geophysical mechanisms for producing them, in Rafter, T $A$ and Grant-Taylor, $T$, eds, Internatl conf on radiocarbon dating, 8th, Proc: Wellington, Royal Soc New Zealand, p A44-57.

\section{DISCUSSION}

Barton: Regarding Dr Vogel's reference to the Lake Mungo geomagnetic excursion and to the paper given by Dr. Barbetti this morning, may I point out that field strengths associated with geomagnetic excursions are probably not representative of the global average. They should, therefore, be used cautiously when considering geomagnetic modulation of atmospheric ${ }^{14} \mathrm{C}$ levels. R Coe's (1977) dipole source model of the Mungo excursion illustrates the point.

REFERENCE

Coe, R, 1977, Source models to account for Lake Mungo palaeomagnetic excursion and their implications: Nature, v 269, p 48-51. 